\title{
RELIQUIAS DEL PASADO. EL COLECCIONISMO Y EL ESTUDIO DE LAS ANTIGÜEDADES PRECOLOMBINAS EN EL PERÚ Y CHILE, 1837-1911 (2019)
}

Stefanie Gänger. Instituto Francés de Estudios Andinos; Instituto Riva Agüero.

doi: https://doi.org/10.26439/en.lineas.generales2021.n5.5428

Raúl Kuroki Tupayachi

Universidad Nacional Mayor de San Marcos

En los últimos veinte años, una serie de autores han dirigido su interés al estudio de los orígenes de la arqueología en el Perú (Kaulicke et al., 2010; Prieto, 2011; Tantaleán y Astuhuamán, 2013; Asensio, 2019). Sin embargo, la profesionalización de la disciplina, junto a la importancia otorgada a sus figuras más descollantes, ha provocado el olvido de procesos anteriores y paralelos. En este sentido, el libro de Stefanie Gänger nos ofrece una historia del coleccionismo, el anticuarismo y la arqueología en el Perú y Chile a través de la reconstrucción de las travesías, tanto espaciales como temporales, que siguieron determinadas piezas arqueológicas y el análisis de las redes de conocimiento que estas propiciaron. Así, siguiendo los rastros de una mascaypacha, un khipu inca, un sujeto indígena araucano y una vasija desenterrada cerca de Valdivia, la historiadora nos muestra un escenario dinámico en torno a la colección de antigüedades desde mediados del siglo XIX, mucho antes del proceso de profesionalización de la arqueología.

La presente edición es la traducción de un primer texto publicado en inglés por Oxford University Press (2014), producto de la tesis doctoral preparada por la autora entre el 2007 y el 2011. El libro está compuesto por cuatro capítulos, cada uno de los cuales se enfoca en el análisis de un objeto específico y su entorno. De esta forma, los dos primeros tratan sobre espacios peruanos, como las ciudades de Cusco y Lima; el tercero, por su parte, se enfoca en los territorios araucanos del norte de Chile; mientras que el último capítulo se orienta a la zona de Atacama, espacio anexado al territorio chileno como consecuencia de la guerra del Pacífico.

Con base en una destacada investigación sobre las fuentes, que incluye diarios de viajeros, cartas y catálogos de colecciones privadas y estatales, se muestra que el coleccionismo era una práctica extendida entre las élites profesionales y propietarias limeñas y cusqueñas. Gänger visibiliza a un grupo de individuos pertenecientes a la esfera pública letrada -abogados, médicos, escribanos, ingenieros, entre otros- que dedicaban su tiempo y parte de sus fortunas familiares a la colección sistemática de antigüedades. En el caso cusqueño, la autora muestra cómo esta afición estaba especialmente relacionada con las viejas familias de notables. En la capital, los coleccionistas y anticuarios 
se movían dentro de los cada vez más extensos círculos burgueses, que incluían a los sectores medios que tenían aspiraciones sociales, en especial inmigrantes provincianos.

A pesar de las peculiaridades encontradas en los estudios de caso - Cusco, Lima y norte de Chile-, algunos temas son constantes a lo largo de toda la investigación realizada por Gänger. Así, un punto importante es el hecho de que el fenómeno del coleccionismo no estuvo vinculado a proyectos estatales de corte nacionalista. Si bien es cierto que aparecen algunos rasgos de regionalismos, especialmente para el caso cusqueño, la labor de coleccionista o de anticuario estaba supeditaba, la mayoría de las veces, a un interés privado, en el que la obtención de prestigio personal era el móvil principal. De este modo, las primeras grandes colecciones que se erigieron en el Perú surgieron en la esfera privada, en medio de amplios salones o casa-museos que regularmente abrían sus puertas a visitas de notables como parte del juego de sociabilidad de las élites. Será recién a finales del siglo XIX, en el contexto de la reconstrucción nacional y con el posicionamiento de un discurso de progreso y modernización oligárquico, que el Estado buscará monopolizar las diferentes colecciones privadas como parte de su propuesta museográfica nacional. Con ello, una gran cantidad de colecciones fueron adquiridas por los nacientes museos estatales, etapa que coincidió con el inicio del proceso de profesionalización de la arqueología.

Un aporte de este libro radica en acercarnos a un variopinto grupo de individuos que desde mediados del siglo XIX se encontraba imaginando el pasado precolombino del país. Personajes como los ubicados por Gänger otorgaban un valor a determinados objetos en la medida que los vinculaban con una imagen construida por ellos del pasado nacional o regional. De este modo, siguiendo el proceso de conversión de reliquias de algunos elementos, como una mascaypacha o un khipu, podemos encontrar extractos de estas imágenes y la posición social desde donde sus autores las construían. Además, como bien señala la autora, este proceso no solo recayó en objetos materiales, sino que también alcanzó a los sujetos. Así fue posible que la población campesina andina y la araucana, para los casos del Perú y Chile respectivamente, fueran relacionadas con un pasado imaginado y a la postre, más que incorporadas dentro de una narrativa oficial como sujetos nacionales, fueron convertidas también en reliquias.

Gracias a su mirada global, la investigación realizada por Gänger abre una nueva entrada para el estudio de la historia de la ciencia dentro de la historiografía peruana. Como menciona la autora, la labor del coleccionista o anticuario no solo se reducía a la aglomeración de antigüedades, sino que iba acompañaba por un rescatable quehacer académico. Los coleccionistas invertían largas jornadas en investigar acerca de las piezas que conformaban sus colecciones. Consultaban libros, investigaban in situ, conversaban con la población local, entre otros métodos. El conocimiento adquirido era compartido gracias a una red nacional que se encontraba en un marcado crecimiento desde el último 
cuarto del siglo XIX: instituciones privadas, museos, tertulias, revistas, universidades, etcétera. No obstante, los diálogos académicos no solo se llevaban a cabo dentro de territorio peruano, sino que, por el contrario, se buscaba que llegasen a diferentes países. De este modo, Gänger nos lleva por distintos lugares, traspasando fronteras, para mostrar el proceso dialógico entre espacios locales, como Lima o Cusco, y los centros de producción cultural americanista en Europa y Estados Unidos. En el mismo sentido, se observa cómo muchos de los personajes claves en el temprano proceso de profesionalización de la arqueología mantuvieron contacto con estos coleccionistas y anticuarios nacionales, y se valieron de su conocimiento para articular sus propias ideas, aunque en la mayoría de los casos nunca obtuvieron algún tipo de reconocimiento.

La interconectividad académica internacional toma especial relevancia en el caso de la vasija de Valdivia, pieza cerámica en torno a la cual se alzó un debate con respecto al pasado común entre Perú y Chile. A través de este debate, Gänger muestra cómo, en el marco de dos nacionalismos exacerbados por la reciente guerra, la ciencia arqueológica, con vasos comunicantes entre ambos países, también era sensible a las fluctuaciones políticas, demostrando el pragmatismo que pueden encerrar las ciencias sociales.

Por todo lo mencionado, Reliquias del pasado de Gänger resulta un excelente texto no solo para echar luces sobre los fenómenos precedentes a la profesionalización de la arqueología peruana, sino también para comprender la inclusión o exclusión de diferentes grupos de personas dentro de los proyectos nacionales de finales de siglo y la importante influencia de las redes de conocimiento globales en la construcción de un Estado-nación.

\section{REFERENCIAS}

Asensio, R. (2019). Señores del pasado: arqueólogos, museos y huaqueros en el Perú. Instituto de Estudios Peruanos.

Kaulicke, P., Fischer, M., Masson, P., y Wolff, G. (Eds.). (2010). Max Uhle (1856-1944). Evaluaciones de sus investigaciones y obras. Pontificia Universidad Católica del Perú.

Prieto, G. (2011). Dos forjadores de las ciencias sociales en el Perú: sus publicaciones y confrontaciones. Arqueología y Sociedad, 22, 111-144.

Tantaleán, H., y Astuhuamán, C. (2013). Historia de la arqueología en el Perú del siglo XIX. Instituto Francés de Estudios Andinos; Institute of Andean Research. 